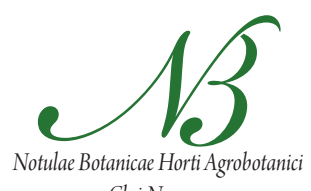

Cluj-Napoca

\title{
Biomass Equations and Carbon Content of Young Black Locust (Robinia pseudoacacia L.) Trees from Plantations and Coppices on Sandy Soils in South-Western Romanian Plain
}

\author{
Alexandru Liviu CIUVĂȚ, ${ }^{1,2}$, Ioan Vasile ABRUDAN ${ }^{1 *}$, Viorel BLUJDEA ${ }^{2,3}$ \\ Ioan DUTCA' ${ }^{1}$ Ilie Silvestru NUTA', Elena EDU² \\ ${ }^{1}$ Transilvania University of Brasov, Faculty of Silviculture and Forest Engineering, 1 Sirul Beethoven Street, 500123 \\ Braşov,Romania; alexandru.ciuvat@gmail.com; abrudan@unitbv.ro ("correspondingauthor) \\ ${ }^{2}$ Forest Research and Management Institute Bucharest, 128 Eroilor Blvd., Voluntari, Romania; viorel_blujdea@yahoo.com; elenam25@yahoo.com \\ ${ }^{3}$ Forest Resources and Climate Unit, Institute for Environment and Sustainability, Joint \\ Research Centre of the European Commission Via Fermi, 21027 Ispra (VA), Italy \\ ${ }^{4}$ Segarcea Forest District, Segarcea-Dolj, Romania; nutas@yahoo.com
}

\begin{abstract}
The aim of the paper was to develop biomass equations for young black locust trees from plantations and coppices established in South-West Romania. A destructive method was used to develop allometric biomass equations and to assess the carbon content of the individual tree and its biomass components. 418 black locust young trees (1-4 years old) from 27 plots established in plantations and coppices growing on sandy soils in Dolj and Olt counties were sampled. Simple linear regression models were developed for biomass estimation. The results shown that root collar diameter was the most accurate biomass predictor, whilst intercept and slope values were similar to those identified in other recent studies. The specific carbon content (mean values) was $45 \%$ for roots and $48 \%$ for leaves, similar to the values provided by Intergovernmental Panel for Climate Change.
\end{abstract}

Keywords: allometry, individual tree components, root collar diameter

\section{Introduction}

Anthropogenic greenhouse gas (GHG) emissions, and especially $\mathrm{CO}_{2}$ emissions, are recognised as one of the main causes of global warming, this fact being acknowledged in the 4th Assessment Report of the Intergovernmental Panel for Climate Change (2007). The negative impact of planetary climatic changes was also identified in Romania (Pienaru et al., 2009), especially in areas with very low percentage of forests, located in the southern part of the country (Lower Danube Plain). Such areas are prone to desertification, due to the prolonged droughts and high temperatures recorded during the summer (above $40^{\circ} \mathrm{C}$ ). In order to mitigate the effects of climate, several local communities and forestry administration initiated an afforestation program for the degraded agricultural lands. The main species established on such lands is black locust (Robinia pseudoacacia L.).

On the other hand, Romania, as any other part of Annex I to United Nations Framework Convention on Climate Change (UNFCCC) and as a country which ratified the Kyoto Protocol, accounts for Land Use, Land Use Change and Forestry (LULUCF) activities to demonstrate compliance with its emission reduction target. For this purpose it conducts a National Greenhouse Gas
Inventory, as obligations under UNFCCC (and European Union commitments) and implements GHG emissions reductions and carbon sequestration activities. In order to report consistent and accurate national data on carbon stocks and $\mathrm{CO}_{2}$ removal by forest ecosystems, allometric equations are considered the most reliable data source (Blujdea et al., 2012; IPCC, 2006), whilst some authors underlines that such equations are of international importance (Basuki et al., 2009; Olofsson et al., 2011; Parresol, 2009).

The aim of this paper was to provide species - specific biomass equations for young black locust trees (1- 4 years old) from plantations and coppices established on sandy soils. Such equations are very important considering the general lack of allometric data for young/small trees, required for the national reports on GHG removal in the case of degraded agricultural land afforestation, especially in South-Eastern Europe.

\section{Material and methods}

The research has been carried out in the southern part of Dolj and Olt counties (Băileşti and Caracal plains), in areas characterized by mean annual temperatures above $10{ }^{\circ} \mathrm{C}$ and a mean annual rainfall of $570 \mathrm{~mm} .27$ circular 
sample plots (SP) of $200 \mathrm{~m}^{2}$ were installed in $1-4$ years old pure black locust plantations and coppice stands (of a an area of minimum 0.5 hectares) established on sandy soils. The root collar diameter $(\mathrm{DCH}, \mathrm{mm})$, the diameter at breast height $(\mathrm{DBH}, \mathrm{cm})$ - where available, and the total tree height $(\mathrm{H}, \mathrm{cm})$ were measured for each individual tree of the sample plots. The destructive sampling method (Böhm et al., 2012; Picard et al., 2012) was applied in order to measure the dry biomass for 418 trees: 225 seedlings and 193 shoots (5-10 individuals for each $2 \mathrm{~cm}$ diameter class identified in each sample plot). Afterwards, biomass equations were developed at tree level (seedling or stump shoot/root sucker), for biomass components (i.e. root, stem, branches, leaves) and the aggregated ones (total biomass and above ground woody biomass -AGWB). Organic carbon content of biomass was determined for 73 component samples (root, stem, branches and leaves) collected from 21 individual trees (14 seedlings and 7 shoots), using the dry Dumars combustion method (Edu et al., 2013).

The allometric model for biomass estimation used in this study was a power one with a single predictor. This approach was justified by the fact that each of the utilised predictors ( $\mathrm{DCH}, \mathrm{DBH}$ and $\mathrm{H})$ explained more than $90 \%$ of the variance of biomass.

The assumptions of linear regression (i.e. linearity, independence, homoscedasticity and normality) cannot be tested for power equations. Therefore, the variables were $\log$ transformed using the natural logarithm, from a power model $\left(\mathrm{B}=\mathrm{a} \times \mathrm{D}^{\mathrm{b}}\right)$ to a linear regression model $[\ln (\mathrm{B})=$ $\ln (\mathrm{a})+\mathrm{b} \ln \mathrm{D}$ ], where $\mathrm{B}$ is the biomass (grams), $\mathrm{D}$ is the predictor - $\mathrm{DCH}(\mathrm{mm}), \mathrm{DBH}(\mathrm{mm})$ or $\mathrm{H}(\mathrm{cm})$, $\mathrm{a}$ and $\mathrm{b}$ regression coefficients.

After testing the linear regression assumptions, the equations were transformed back. This transformation induces a bias which can be reduced by adopting a correction factor (CF) proposed by Sprugel (1983) and based on standard error of the estimate. Thus, the final form of the biomass equation was:

$$
\mathrm{B}=\mathrm{CF} \times \mathrm{e}^{(\ln (\mathrm{a})+\mathrm{b} \ln (\mathrm{D}))}
$$

$R$ version 3.0.1 for Windows - open source software ( $R$ Core Team, 2013) was used to do the statistical analysis of the datasets.

\section{Results and discussion}

After testing the linear regression assumptions (Fig. 1), the developed allometric models shown that $\mathrm{DCH}$ is the best predictor both for the total biomass of the individual tree and for its biomass components. The regression coefficients of the $\mathrm{DCH}$ based equations developed for black locust are presented in Tab. 1, both for seedlings (plantation) and shoots (coppice) of ages between 1 and 4 years. Values of intercept $[\ln (\mathrm{a})]$ and slope (b) are statistically significant in all cases $(\mathrm{p}<0.001)$.
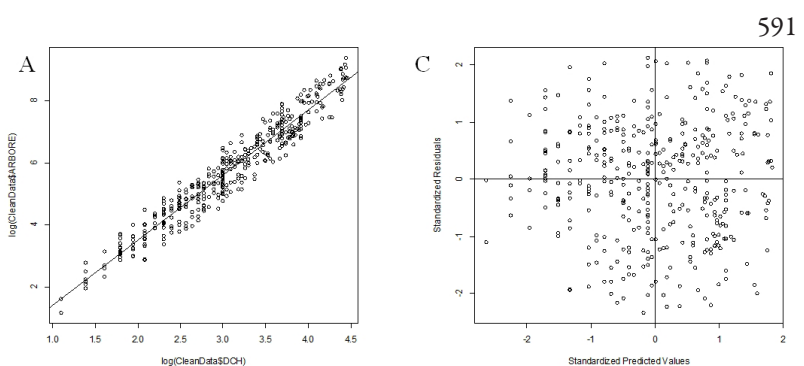

B
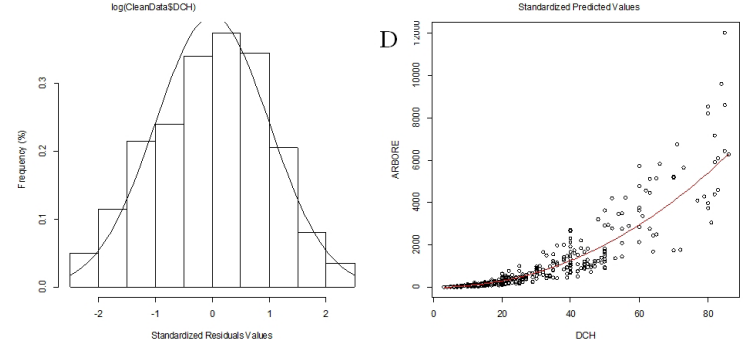

Fig. 1. The statistical testing of the linear regression assumptions: linearity (A) of inputs and residuals normality (B) and heteroscedasticity $(\mathrm{C})$ and the regression curve $(\mathrm{D})-\mathrm{DCH}$ as predictor (R outputs)

The model based on $\mathrm{DCH}$ as a biomass predictor explains between $85-98 \%$ of the variability of the dependent variable; nevertheless, the lower $\mathrm{R}^{2}$ values for leaves of shoots (coppice) indicate a precautious approach in using $\mathrm{DCH}$ as a biomass predictor for this tree component. As observed from Tab. 1, the model estimates better the biomass for planted seedlings. The low values of the standard error of mean (SEM) and the very significant Fischer test (F) values also indicate the model robustness.

The intercept values are consistent with those published by Blujdea et al. (2012), while slope values are close to those developed by Pilli et al. (2006) for young trees (2.09). CF values varied significantly, recording higher values for smaller samples or where the model fails to achive high explicative power (e.g. leaves biomass for shoots/ sprouts).

The specific carbon content of tree components in black locust plantations and coppices is presented in Tab. 2. It can be noticed that the specific carbon content (mean values) was $45 \%$ for roots and $48 \%$ for leaves, similar to the values provided by IPCC (2006) (46-50\%).

\section{Conclusions}

The log-transformed power equation proved to be a suitable allometric model to estimate biomass in young black locust plantation and coppices. Among the analysed predictors, the root collar diameter $(\mathrm{DCH})$ represented the most adequate biomass predictor. The measured carbon content of tree components confirmed the validity for young black locust trees of the IPCC recommended generic values. 
Tab. 1. The regression coefficients and the results of the model validity testing - DCH as predictor

\begin{tabular}{|c|c|c|c|c|c|c|}
\hline Biomass component & $\ln (a) \pm S E M$ & $\mathrm{~b} \pm \mathrm{SEM}$ & $\mathrm{CF}$ & $\mathrm{R}^{2}$ & $\mathrm{~F}$ & $\mathrm{p}$ \\
\hline \multicolumn{7}{|c|}{ Seedlings (plantation) } \\
\hline Roots & $-2.45061 \pm 0.13921$ & $2.30782 \pm 0.04473$ & 1.134352 & 0.9253 & 2662 & $<0.001$ \\
\hline Stem & $-2.22443 \pm 0.09569$ & $2.26553 \pm 0.03057$ & 1.060552 & 0.9637 & 5493 & $<0.001$ \\
\hline Branches & $-5.83327 \pm 0.25313$ & $3.09105 \pm 0.07758$ & 1.288592 & 0.8987 & 1587 & $<0.001$ \\
\hline Leaves & $-1.33825 \pm 0.13740$ & $1.93595 \pm 0.04399$ & 1.139922 & 0.9005 & 1936 & $<0.001$ \\
\hline Total tree & $-0.97829 \pm 0.06863$ & $2.26105 \pm 0.02202$ & 1.054000 & 0.9803 & 10540 & $<0.001$ \\
\hline AGWB & $-2.57776 \pm 0.08932$ & $2.4642 \pm 0.02852$ & 1.052861 & 0.9733 & 7661 & $<0.001$ \\
\hline \multicolumn{7}{|c|}{ Stump shoots/root suckers (coppice) } \\
\hline Stem & $-1.95865 \pm 0.10809$ & $2.26294 \pm 0.03342$ & 1.049837 & 0.9624 & 4586 & $<0.001$ \\
\hline Branches & $-5.00710 \pm 0.28800$ & $2.69595 \pm 0.08691$ & 1.291361 & 0.8514 & 962.2 & $<0.001$ \\
\hline Leaves & $-0.0569 \pm 0.4013$ & $1.5162 \pm 0.1542$ & 1.229705 & 0.5665 & 96.71 & $<0.001$ \\
\hline Total tree & $-0.47992 \pm 0.13385$ & $1.94177 \pm 0.04117$ & 1.081935 & 0.924 & 2224 & $<0.001$ \\
\hline AGWB & $-1.96634 \pm 0.10492$ & $2.33189 \pm 0.03236$ & 1.050143 & 0.9665 & 5194 & $<0.001$ \\
\hline
\end{tabular}

Tab. 2. The specific carbon content of tree components (plantations and coppices)

\begin{tabular}{|c|c|c|c|c|c|c|c|}
\hline \multirow{2}{*}{ Regeneration type } & \multirow{2}{*}{ No. of samples } & \multirow{2}{*}{ Age class (years) } & \multirow{2}{*}{$\begin{array}{c}\text { DCH category } \\
(\mathrm{cm})\end{array}$} & \multicolumn{4}{|c|}{ Specific C content (\%) } \\
\hline & & & & Roots & Stem & Branches & Leaves \\
\hline \multirow{3}{*}{ Plantations } & 7 & $1-3$ & $0.1-2$ & $44-47$ & $46-49$ & $46-49$ & $45-51$ \\
\hline & 5 & $3-4$ & $2.1-4$ & $45-47$ & $46-49$ & $47-48$ & $47-50$ \\
\hline & 2 & 4 & $4.1-6$ & $45-46$ & $44-48$ & 48 & $47-49$ \\
\hline \multirow{3}{*}{ Coppices } & 3 & $1-4$ & $0.1-2$ & $\mathrm{NA}$ & $48-49$ & $49-50$ & $47-49$ \\
\hline & 1 & 2 & $2.1-4$ & NA & 49 & 49 & NA \\
\hline & 3 & $3-4$ & $4.1-6$ & NA & $47-49$ & $48-49$ & NA \\
\hline
\end{tabular}

\section{Acknowledgements}

This paper is supported by the Sectoral Operational Programme Human Resources Development (SOP HRD), ID76945 financed from the European Social Fund and by the Romanian Government.

\section{References}

Basuki TM, van Laake PE, Skidmore A.K, Hussin YA (2009). Allometric equations for estimating the above-ground biomass in tropical lowland Dipterocarp forests. Forest Ecology and Management 257:1684-1694.

Blujdea V, Pilli R, Dutca I, Ciuvat L, Abrudan IV (2012). Allometric biomass equations for young broadleaved trees in plantations in Romania. Forest Ecology and Management 264:172-184.

Böhm C, Quinkenstein A, Freese D (2011). Yield prediction of young black locust (Robinia pseudoacacia L.) plantations for woody biomass production using allometric relations. Ann For Res 54(2):215-227.

Edu E M, Mihalache M, Ionescu M (2013). Determination of organic carbon in forest soils by comparative analysis of method: Walkley Black method with the Gogoasa modification versus Dry combustion Dumars method. Research Journal of Agricultural Science 45(1):13-19.

IPCC (2006). Guidelines for national greenhouse gas inventories. Prepared by the National Greenhouse Gas Inventories Programme, edited by H.S. Eggleston, L. Buendi, K. Miwa, T. Ngara and K. Tanabe.Kanagawa: Intergovernmental Pan- el on Climate Change, Institute for Global Environmental Strategies.

Olofsson P, Kuemmerle T, Griffiths P, Knorn J, Baccini A, Gancz V, Blujdea V, Houghton RA, Abrudan IV, Woodcock CE (2011). Carbon Implications of Forest Restitution in Post-Socialist Romania. Environmental Research Letters 6(4):10 p.

Pienaru A, Iancu P, Căzănescu S (2009). Desertification and its effects on environment and agricultural production in Romania. Annals of Food Science and Technology 10(2):624629.

Parresol BR (1999). Assessing tree and stand biomass: A review with examples and critical comparisons. Forest Science 45(4):573-593.

Picard N, Saint-André L, Henry M (2012). Manual for building tree volume and biomass allometric equations: from field measurement to prediction. FAO, Rome and Centre de Coopération Internationale en Recherche Agronomique pour le Développement, Montpellier, 215 pp.

Pilli R, Anfodillo T, Carrer M (2006). Towards a functional and simplified allometry for estimating forest biomass. Forest Ecology and Management 237:583-593.

R Core Team (2013). R: A language and environment for statistical computing. R Foundation for Statistical Computing, Vienna, Austria. URL http://www.R-project.org.

Sprugel DG (1983). Correcting for bias in log-transformed allometric equations. Ecology 64:208-210. 